\title{
Pelaksaan Perjanjian Terapeutik Antara Pasien dengan Rumah Sakit Jiwa Jambi
}

\author{
Supeno $^{1 *}$, Fachruddin Razi ${ }^{2}$, Fauty Intan Faradila ${ }^{3}$ \\ ${ }^{1,2,3}$ Fakultas Hukum Universitas Batanghari \\ *Correspondence email: supeno@unbari.ac.id, fautyintanf@gmail.com
}

\begin{abstract}
Abstrak. Pada umumnya perjanjian adalah suatu kesepakatan yang dilakukan oleh kedua pihak atau lebih tentang sesuatu yang mereka setujui, dan didalam perjanjian berisikan hak serta kewajiban dari masing-masing pihak tersebut. Didalam kajian ini merumuskan bagaimana pelaksanaan perjanjian di rumah sakit jiwa karena pasiennya mengalami gangguan kejiwaan sehingga tidak cakap untuk melakukan perjanjian sehingga diwakilkan oleh keluarga/wali pasien serta permasalahan apa yang terjadi tentang hak maupun kewajiban yang tidak diperoleh atau tidak dilaksanakan. ketika pasien tersebut tidak cakap dan berkompeten untuk melakukan persetujuan tindakan kedokteran.Dapat atau tidaknya seorang pasien dengan gangguan kejiwaan melakukan persetujuan, juga mempengaruhi kewajiban wali atau penanggung jawab pasien, karena wali merupakan orang yang bertanggung jawab atas diri pasien, setelah sepakat maka dengan demikian kedua belah pihak terikat dalam perjanjian terapeutik.Tetapi dalam pelaksanaan perjanjian terapeutik tersebut tidak selalu dapat dilaksanakan dengan semestinya, Tujuan dari penelitian ini yaitu untuk mengetahui bagaimana isi perjanjian antara rumah sakit dengan pasien rumah sakit jiwa, permasalahan apa saja yang terjadi dalam pelaksanaan perjanjian antara rumah sakit jiwa dengan pasien dan bagaimana penyelesaian permasalahan yang terjadi antara rumah sakit dengan pasien rumah sakit jiwa Jambi. Hasil penelitian menunjukkan bahwa pihak rumah sakit dan pasien terikat dalam suatu perjanjian baku yang didalamnya terdapat masing-masing hak dan kewajiban kedua belah pihak, permasalahan yang terjadi adalah perlakuan negatif dari tenaga medis terhadap pasien rumah sakit jiwa, kelalaian yang dilakukan oleh keluarga pasien terhadap rumah sakit, penyelesaian permasalahan yang terjadi diselesaikan dengan musywarah dan pihak rumah sakit langsung mengunjungi pihak keluarga yang menelantarkan keluarganya di rumah sakit jiwa Jambi.
\end{abstract}

Kata Kunci: Perjanjian terapeutik, pasien, rumah sakit jiwa

\begin{abstract}
Generally an agreement is an agreement made by both parties or more about something they agree to, and in the agreement contains the rights and obligations of each party. In this study formulates how the implementation of the agreement in a mental hospital because the patient has a psychiatric disorder so incapable to do the agreement so represented by the family $/$ guardian of the patient and the problem of what happens about rights or obligations that are not obtained or not implemented. when the patient is incapable and competent to approve medical measures. Whether or not a patient with a psychiatric disorder consents, it also affects the obligations of the guardian or the person in charge of the patient, because the guardian is the person in charge of the patient, after agreeing that both parties are bound by the therapeutic agreement. But in the implementation of the therapeutic agreement can not always be implemented properly, the purpose of this study is to find out how the contents of the agreement between the hospital and the mental hospital patient, what problems occur in the implementation of the agreement between the mental hospital and the patient and how to solve the problems that occur between the hospital and the patient of jambi mental hospital. The results showed that the hospital and patients are bound in a standard agreement in which there are each right and obligation of both parties, the problem that occurs is the negative treatment of medical personnel to mental hospital patients, negligence done by the patient's family to the hospital, the resolution of problems that occur solved by musywarah and the hospital directly visit the family who abandoned his family in jambi mental hospital.
\end{abstract}

Keywords: Therapeutic agreements, patients, mental hospitals

\section{PENDAHULUAN}

Menurut Pasal 1313 KUHPerdata perjanjian adalah perbuatan dengan nama satu orang atau lebih mengikatkan dirinya terhadap satu ang tau lebih. Dari suatu perjanjian akan menimbulkan suatu hubungan hukum antara dua orang atau lebih yang disebut perikatan yang didalamnya terdapat hak dan kewajiban dari masing masing pihak. ${ }^{1}$ Istilah hukum perjanjian mempunyai cukupan yang lebih sempit dibandigkan dengan istilah perikatan, dan sejatinya perjanjian merupakan bagian dari perikatan, dalam istilah hukum disebut perikatan yang timbul karena perjanjian.dalam beberapa literature ada yang mengunakan istilah hukum kontrak disamping hukum perjanjian. ${ }^{2}$

Perjanjian di dunia kesehatan dinamakan perjanjian terapeutik.Perjanjian terapeutik atau transaksi terapeutik sendiri adalah perjanjian antara dokter dengan pasien yang memberikan kewenangan kepada dokter untuk melakukan kegiatan memberikan pelayanan kesehatan kepada pasien berdasarkan keahlian dan keterampilan yang dimiliki oleh

\footnotetext{
1 Supeno, Dasar-Dasar Hukum Perikatan, Salim Media Indonesia, Jambi, 2019, Hlm.19.

2 Sarah Quroti A'yun, Dewi Hendrawati, Aminah, Pelaksanaan Perjanjian Terapeutik Antara Pasien Yang Mengalami Kegawatdaruratan Dengan Rs Bhayangkara Semarang, Diponegoro Law Journal, Volume 6 Nomor 2, 2017 , Hlm.11.
} 
dokter tersebut. Hal ini dilakukan setelah ia mendapat informasi dari dokter mengenai upaya medis yang dapat dilakukan untuk menolong dirinya, termasuk memperoleh informasi mengenai segala resiko yang mungkin terjadi

Hubungan hukum antara pasien dengan rumah sakit bermula dari transaksi Terapeutik, pada saat pasien datang ke rumah sakit untuk berkosultasi tentang kondisi kesehatannya terjadi komunikasi antara pasien dengan dokter, pasien menyampaikan keluhannya dan dokter menyampaikan upaya apa yang dapat dilakukan dokter terhadap pasiennya, kemudian pasien menginginkan suatu tindakan dari dokter dan sebaliknya dokter menawarkan tindakan yang dapat dilakukan dokter beserta kemungkinan-kemungkinan yang akan terjadi.

Rumah sakit menurut Undang-undang Nomor 44 Tahun 2009 Tentang Rumah Sakit adalah institusi pelayanan kesehatan yang menyelenggarakan pelayanan kesehatan perorangan secara paripurna yang menyediakan pelayanan rawat inap, rawat jalan, dan gawat darurat. Dalam hal ini rumah sakit dimaksudkan sebagai sarana kesehatan yang menyelenggarakan pelayanan kesehatan terhadap diri seseorang dan dilakukan secara paripurna, selain menyelenggarakan rawat inap dan rawat jalan juga menjalankan pelayanan kegawatdaruratan. ${ }^{3}$

Hak pasien sebenarnya merupakan hak yang asasi yang bersumber dari hak dasar individu dalam bidang kesehatan, (the right of selfdetermination), meskipun sebenarnya sama fundamentalnya, namun hak atas pelayanan kesehataan sering dianggap lebih mendasar, dalam hubungan dokter-pasien,secara relatif pasien berada dalam posisi yang lemah, kekurang mampuan pasien untuk membela kepentingannya dalam situasi pelayanan kesehatan menyebabkan timbulnya kebutuhan untuk kesehatan. ${ }^{4}$

Pasal 31 dan 32 Undang-Undang No.44 Tahun 2009 mengatur tentang kewajiban dan hak pasien dengan rumah sakit yang bertujuan untuk memberi pedoman yang jelas bagi kedua belah pihak tentang kewajiban dan hak yang timbul dalam hubungan hukum, dengan demikian diharapkan akan terjalin hubungan yang baik bagi pasien dan rumah sakit. Hak pasien sebenarnya merupakan hak yang asasi yang bersumber dari hak dasar individu dalam bidang kesehatan, (the right of selfdetermination), meskipun sebenarnya sama fundamentalnya, namun hak atas pelayanan kesehataan sering dianggap lebih mendasar, dalam hubungan dokter-pasien,secara relatif pasien berada dalam posisi yang lemah, kekurang mampuan pasien untuk membela kepentingannya dalam situasi pelayanan kesehatan menyebabkan timbulnya kebutuhan untuk kesehatan. ${ }^{5}$

Kondisi pasien yang demikian menjadi persoalan ketika pasien tersebut tidak cakap dan berkompeten untuk melakukan persetujuan tindakan kedokteran.Dapat atau tidaknya seorang pasien dengan gangguan kejiwaan melakukan persetujuan, juga mempengaruhi kewajiban wali atau penanggung jawab pasien, karena wali merupakan orang yang bertanggung jawab atas diri pasien, setelah sepakat maka dengan demikian kedua belah pihak terikat dalam perjanjian terapeutik.Tetapi dalam pelaksanaan perjanjian terapeutik tersebut tidak selalu dapat dilaksanakan dengan semestinya, baik dari pihak rumah sakit maupun keluarga pasien. Terkadang terjadi permasalahanpermasalahan yang berhubungan dengan hak-hak dan kewajiban masing-masing pihak yang telah disepakati tetapi tidak terlaksana atau diperoleh.

Seperti halnya di Rumah Sakit Jiwa Jambi, jika dilihat dari data pasien rawat inap di Rumah Sakit Jiwa Jambi terjadi pengurangan dan penambahan pasien setiap tahunnya yakni pada tahun 2017 terdapat 1.315 pasien, pada tahun 2018 terdapat 1.312 pasien, dan pada tahun 2019 terdapat 1.319 pasien, maka dari itu saya tertarik untuk mengkaji lebih lanjut dalam penelitianyang saya beri judul Pelaksaan Perjanjian Terapeutik Antara Pasien Dengan Rumah Sakit Jiwa Jambi.

\section{HASIL DAN PEMBAHASAN}

\section{Isi Perjanjian Terapeutik Antara Pasien dan Rumah Sakit Jiwa Jambi}

Dalam peraturan Menteri Kesehatan RI Nomor 585 Tahun 1989tentang Persetujuan Tindakan Medis, disebutkan bahwa yang dimaksuddengan persetujuan tindakan medis adalah persetujuan yang diberikan pasienatau keluarganya atas dasar penjelasan mengenai tindakan medis yang akandilakukan terhadap pasien. Penjelasan yang harus diberikan meliputi:

1. Alasan perlunya dilakukan tindakan medis.

2. Sifat tindakan medis tersebut, yaitu :
a. Eksperimen
b. Bukan eksperimen

3. Tujuan tindakan medis tersebut, yaitu :

a. Diagnostic

b. Terapeutik

${ }^{3}$ Supeno, Kajian Yuridis Penyelesaian Sengketa Medik di Indonesia, Wajah Hukum, Volume 3 Nomor 2, 2019, Hlm. 202. 88.

5 Ibid, Hlm. 88. 


\section{c. Rehabilitatif \\ d. Promotif}

4. Risikonya

5. Akibat ikutan yang tidak menyenangkan

6. Masih ada tindakan medis alternatif atau tidak

7. Kerugian yang akan atau mungkin dialami jika menolak tindakan medis tersebut

Cara penyampaian isi harus sesuai dengan tingkat pendidikan dan kondisi pasien adalah bahwa dalam memberikan informasi tidak boleh bersifat memperdaya (Fraud), menekan (Force) atau menciptakan ketakutan (Fear) sebab ketiga halituakan membuat persetujuan yang diberikan menjadi cacat hukum. ${ }^{6}$

Persetujuan tindakan medis mempunyai prinsip-prinsip secara garis besar adalah :

1. Masalah kesehatan seseorang adalah tanggung jawab sendiri orangitu sendiri.

2. Bahwa hasil dari tindakan kedokteran akan lebih berguna apabilaterjalin kerja sama yang baik antara pasien dan dokter.

3. Bahwa tindakan kedokteran yang dilakukan dokter untukmenyembuhkan penderitaan pasien hanya merupakan upaya yang tidak wajib diterima oleh pasien, karena dalam pelayanan kesehatantidak seorangpun dapat memastikan hasil akhir dari upaya pelayanankesehatan yang dilakukan. ${ }^{7}$

Dalam Peraturan Menteri Kesehatan RI Nomor 585 Tahun 1989tentang Persetujuan Tindakan Medis, disebutkan bahwa yang dimaksuddengan persetujuan tindakan medis adalah persetujuan yang diberikanpasien atau keluarganya atas dasar penjelasan mengenai tindakan medisyang akan dilakukan terhadap pasien atau keluarga atas dasar penjelasanmengenai tindakan medis yang dilakukan terhadap pasien tersebut. Sedang yang dimaksud tindakan medis dalam hal ini adalah suatutindakan yang dilakukan terhadap pasien berupa diagnostik atauterapeutik. Dari pengertian tersebut tidak menjelaskan jenis tindakan apasaja yang termasuk tindakan medis. Berdasar Peraturan MenteriKesehatan RI Nomor 585 Tahun 1989 tentang Persetujuan TindakanMedis.

Undang-Undang Nomor 29 tahun 2004 tentang PraktikKedokteran, dalam pasal 45 ayat 1 mengatur bahwa setiap tindakankedokteran terhadap pasien harus mendapat persetujuan dari pasien. Dan dalam Pasal 2 diatur bahwa persetujuan sebagaimana dimaksud pada ayat 1 diberikan setelah pasien mendapat penjelasan secara lengkap. Persetujuan tindakan kedokteran di dalam Undang-Undang Nomor 29 Tahun 2004 tidak menjelaskan secara detil tapi bila dilihat pasal 81 diatur bahwa semua peraturan perundangan tentang kesehatan yang berkaitan dengan praktek kedokteran masih berlaku sepanjang tidak bertentangan dengan dan atau belum diganti berdasarkan Undang-undang ini. Maka pengertian mengenai persetujuan tindakan medis dokter masih tetap menggunakan pengertian yang ada di dalam Peraturan Menteri Kesehatan RI Nomor 585 Tahun 1989 tentang Persetujuan Tindakan Medis.Persetujuan tindakan medis merupakan terjemahan dari kata Informed Consent. "Informed" berarti persetujuan, sebab informed consent merupakan pernyataan sepihak dari orang yang berhak (yaitu pasien, keluarga atau walinya) yang berisi berupa ijin atau persetujuan kepada dokter untuk melakukan tindakan medis setelah orang yang berhak tersebut memperoleh informasi secukupnya, sehingga Informed consent yang merupakan sarana legitimasi bagi dokter untuk melakukan intervensi medis yang mengandung risiko serta akibat yang tidak menyenangkan, dan membebaskan dokter dari tanggung jawab hukum atas terjadinya risiko serta akibat yang tidak menyenangkan saja.

Persetujuan untuk tindakan medis berdasarkan Pasal 10 PeraturanMenteri Kesehatan Nomor 589 Tahun 1989 yang berhakmenandatangani perjanjian adalah pasien tersebut yang telah dewasayaitu di atas 21 tahun atau sudah menikah dan dalam keadaan sehatmental. Sedangkan pasien di bawah 21 tahun atau belum menikah danmenderita gangguan jiwa maka yang berhak menandatangani perjanjianpersetujuan tindakan medis adalah orang tua atau wali atau keluargaterdekat atau induk semangnya.Hal tersebut berdasarkan Pasal 11Peraturan Menteri Kesehatan Nomor 589 Tahun 1989.

Menurut Ibu Sutiyanik, AMK selaku Kepala Instalasi Rawat Inap di Rumah Sakit Jiwa Jambi prosedur yang dilakukan dalam menerima pasien yaitu yang pertama keluarga/wali pasien diharuskan mengisi lembar identifikasi pasien baru yang berisi data pribadi pasien secara lengkap. Jika pasien diharuskan rawat inap maka keluarga/wali pasien harus mengisi lembar surat persetujuan rawat inap. Kemudian keluarga/wali pasien akan dijelaskan dan diberikan lembaran berisikan hak dan kewajiban pasien di RSJD Jambi yang harus dipahami setelah itu pihak penanggung jawab pasien harus menandatangani persetujuan umum/general consent yang diberikan Rumah Sakit.

\footnotetext{
6 J. Guwandi, Hukum Medik (Medical Law),Jakarta, Balai Penerbit FK UI, 2004, hlm. 43.

7 Ahmadi Miru, Hukum Kontrak dan Perancangan Kontrak, (Jakarta:Rajawali Pers, 2007) hlm. 74.
} 


\section{Permasalahan yang Terjadi Dalam Pelaksanaan Perjanjian Terapeutik di Rumah Sakit Jiwa Jambi}

Dalam suatu perjanjian berarti terdapat sebuah kesepakatan antara kedua belah pihak yang melakukan perjanjian tersebut. Perjanjian yang dimaksud berisikan hak dan kewajiban masing-masing pihak, yaitu pasien berhak mendapatkan hak-hak nya dan harus melakukan kewajiban-kewajibannya begitu juga dengan pihak rumah sakit yang berhak mendapat haknya dan harus melakukan kewajibannya sesuai dengan kesepakatan.

Menurut Ahmadi Miru wanprestasi dalam perjanjian itu dapat berupa perbuatan : ${ }^{8}$

1. Sama sekali tidak memenuhi prestasi.

2. Prestasi yang dilakukan tidak sempurna.

3. Terlambat memenuhi prestasi.

4. Melakukan apa yang dalam perjanjian dilarang untuk dilakukan

Selain masalah-masalah fisik yang terjadi pada pasien saat pengobatan, terkadang ada juga masalah-masalah yang terjadi akibat kelalaian/kesalahan petugas kesehatan di rumah sakit jiwa tersebut bahkan kelalaian dari pihak pasien/keluarga pasien seperti beberapa contoh permasalahan yang ada di Rumah Sakit Jiwa Jambi yaitu :

\section{Perlakuan negatif dari petugas kesehatan kepada pasien.}

Merawat pasien dengan gangguan jiwa tentu berbeda dengan merawat pasien dengan gangguan fisik. Penanganan pasien penyakit jiwa membutuhkan kesabaran dan ketelatenan yang tinggi karena karakteristik pasien penyakit jiwa yang unik, yaitu sulit diajak berkomunikasi, bahkan cenderung agresif.

Kondisi mental serta sikap pasien penyakit jiwa yang labil memaksa perawat untuk bersikap sabar dalam melaksanakan tugasnya, untuk mengetahui apa yang dibutuhkan oleh pasien penyakit jiwa. Wajar apabila seorang perawat jiwa mengalami tekanan ketika menjalani pekerjaannya. Tekanan yang dialami perawat terkait dengan beban pekerjaannya yang cukup berat Setiap hari perawat dihadapkan pasien-pasien penyakit jiwa yang mempunyai karakteristik yang berbeda dengan pasien biasa, antara lain sulit diajak berkomunikasi, sulit diatur, bahkan cenderung agresif. Perawat dituntut untuk selalu siaga ketika berhadapan dengan para pasien penyakit jiwa.Apabila seorang perawat kurang mampu mengontrol emosinya ketika berhadapan dengan pasien penyakit jiwa, maka dapat terjadi perilaku antisosial, salah satunya adalah perilaku agresif.

Salah satu stressor pada perawat pasien penyakit jiwa adalah karakteristik pasien penyakit jiwa yang negatif seperti sulit diajak berkomunikasi, agresif, dan lain-lain. Keadaan dimana tekanan-tekanan pekerjan lebih berat karena setiap hari mengurus dan merawat pasien penyakit jiwa mengharuskan perawat pasien penyakit jiwa untuk mampu mengendalikan dan bertindak sesuai dengan tata cara perawatan sehingga tidak membahayakan diri dan pasien. Keadaan yang rentan dapat menyebabkan stres tersebut juga dapat menyebabkan individu menjadi kurang dapat mengontrol diri dan tingkah lakunya.Keadaan ini dapat menyebabkan individu melakukan tindakan-tindakan yang disebut perilaku antisosial, termasuk perilaku agresif.Kenyataannya sering dijumpai perawat rumah sakit yang kurang bertanggung jawab dalam bekerja dan melakukan tindakan agresif baik melalui fisik atau verbal (lisan) terhadap pasiennya.

Perilaku agresif yang ditunjukkan oleh sebagian oknum perawat pasien penyakit jiwa di rumah sakit biasanya yang meliputi kekerasan fisik dan kekerasan verbal, contohnya membentak, memukul, menampar, dan lain-lain. Hal tersebut dilakukan karena perawat pasien penyakit jiwa merasa kewalahan menghadapi pasien penyakit jiwa yang sulit diatur.Perilaku perawat pasien penyakit jiwa yang cenderung agresif tersebut tentu bertentangan dengan kode etik keperawatan.

Selain itu, menurut Bapak AF selaku pihak keluarga yang pernah dirawat di rumah sakit jiwa jambi, masalah perlakuan negatif dari petugas kesehatan memang sering kali terjadi tetapi pihak keluarga tidak bisa sepenuhnya menyalahkan petugas karena pihak keluarga memahami bahwa pasien yang menderita gangguan kejiwaan sudah pasti berbeda dengan pasien normal pada umumnya.

\section{Kelalaian pihak keluarga/wali pasien yang tidak menjemput kembali pasien di Rumah Sakit Jiwa Jambi.}

Tidak hanya permasalahan dari kesalahan atau kelalaian pihak rumah sakit saja, tetapi ada juga permasalahan yang terjadi karena kelalaian atau kesalahan pihak keluarga pasien/wali pasien.

Permasalahan dari kesalahan keluarga/wali pasien yang terkait dengan hak dari pihak rumah sakit menurut dr.Riza yaitu misalnya pasien yang ditelantarkan oleh pihak keluarganya atau pasien tidak dikontrol atau dijemput kembali dengan pihak keluarganya, seolah-olah pihak keluarga melepaskan tanggung jawab penuh kepada pihak rumah sakit dan tidak memperdulikan pasien. Beberapa alasan keluarga yang menolak untuk menerima pasien yang telah dinyatakan sembuh yaitu karena malu, dan karena alasan ekonomi, menurut dr. Riza seharusnya bagaimanapun kondisi yang dihadapi keluarga patut untuk menerima keberadaan seseorang yang mengalami gangguan jiwa.

${ }^{8}$ Turdinanto S.Kep. Kepala Ruang Instalasi Gawat Darurat (IGD) Rumah Sakit Jiwa Jambi. Wawancara penulis pada tanggal 27 Juli 2020, Pada Pukul 10.00 WIB. 
Upaya Yang Dilakukan Untuk Mengatasi Permasalahan Yang Terjadi Dalam Perjanjian Terapeutik di Rumah Sakit Jiwa Jambi

Penyelesaian permasalahan akibat kelalaian pihak Rumah Sakit

Dalam Undang-Undang Nomor 36 Tahun 2009 tentang Kesehatan telah diatur hal-hal yang berkaitan dengan masalah kelalaian tenaga kesehatan, yaitu dalam Pasal 29 dan Pasal 58. Pasal 29 menentukan bahwa dalam hal tenaga kesehatan diduga melakukan kelalaian dalam menjalankan profesinya, kelalaian tersebut harus diselesaikan terlebih dahulu melalui mediasi.Pasal 58 mengatur mengenai hak setiap orang untuk menuntut ganti rugi terhadap seseorang, tenaga kesehatan, dan/atau penyelenggara kesehatan yang menimbulkan kerugian akibat kesalahan atau kelalaian dalam pelayanan kesehatan yang diterimanya. ${ }^{9}$

Oleh karenanya dapat dikatakan, penuntutan ganti kerugian ini diakibatkan oleh kesalahan (kesengajaan) ataupun kelalaian dalam pelayanankesehatan, dan penuntutan ditujukan kepada seseorang, tenaga kesehatan maupun kepada pihak penyelenggara kesehatan (rumah sakit).

Lebih lanjut berdasarkan Undang Undang Nomor 44 Tahun 2009 tentang Rumah Sakit, penuntutan kerugian hanya ditujukan kepada pihak rumah sakit, yang diakibatkan secara khusus karena kelalaian tenaga kesehatan di rumah sakit. ${ }^{10}$ Bahwa kerugian yang diakibatkan oleh kesengajaan tenaga kesehatan di rumah sakit, maka tidak dapat dilakukan penuntutan yang ditujukan kepada rumah sakit. Pihak rumah sakit tidak akan bertanggung jawab jika kerugian tersebut karena kesalahan dalam arti kesengajaan tenaga kesehatan di rumah sakit.

Menurut Ibu Dian Apriyatni, S.Psi dari Poli Psikologi Rumah Sakit Jiwa Jambi, seorang perawat pasien penyakit jiwa diharapkan mempunyai sikap yang positif dan menerima pasien apa adanya sehingga dapat menciptakan suasana yang kondusif bagi pasien untuk sembuh dan berkembang, namun kenyataannya terdapat beberapa oknum perawat pasien penyakit jiwa yang melakukan tindakan yang merugikan pasien penyakit jiwa, seperti tindakan agresif.

Semakin positif sikap perawat terhadap pasien, maka perilaku agresifnya semakin rendah.Sebaliknya, semakin negatif sikap perawat terhadap pasien penyakit jiwa, maka perilaku agresifnya semakin tinggi. ${ }^{11}$ Menurut dr. Riza selaku Staf Medis Rumah Sakit Jiwa Jambi, pernah beberapa kali terjadi tuntutan sepihak dari pihak keluarga pasien, pihak rumah sakit dapat mengerti keluhan dari keluarga pasien dan selalu menjelaskan dengan bijaksana bagaimana standar penanganan rumah sakit yang sebenarnya.

Tetapi pengaduan melalui jalur hukum belum pernah terjadi baik dari pihak Rumah Sakit Jiwa Jambi ataupun pengaduan hukum dari pihak keluarga, dan pihak rumah sakit berusaha memberikan pelayanan yang humanis dan manusiawi, semuanya dapat diselesaikan secara kekeluargaan.

Upaya yang dilakukan terkait perilaku negatif dari perawat baik itu fisik maupun verbal jika terjadi pengaduan atau tuntutan dari keluarga pasien maka akan dilakukan mediasi, seperti permohonan maaf langsung yang dilakukan oleh perawat yang bersangkutan.

Upaya lain yang dilakukan untuk kedepannya yaitu bagi perawat pasien jiwa untuk mengikuti penyuluhanpenyuluhan atau pelatihan-pelatihan mengenai pengelolaan emosi untuk mengendalikan perilaku dalam menghadapi pasiennya. Dan akan diajukan kepada pihak Rumah Sakit untuk memberi dukungan dengan sering mengadakan program yang berkaitan dengan pengelolaan emosi ketika menghadapi pasien penyakit jiwa serta mengenai pentingnya sikap positif terhadap pasien penyakit jiwa dan seluruh petugas diharapkan lebih disiplin dalam melaksanakan kegiatan-kegiatan pasien sesuai jadwal yang ditentukan terutama yang merupakan terapi untuk menunjang kesehatan para pasien-pasien dirumah sakit jiwa jambi, untuk sarana prasarana yang kurang memadai pihak rumah sakit akan melakukan perbaikan atau segera mengusahakan agar alat yang dibutuhkan untuk pengobatan dapat tersedia untuk menunjang kesembuhan pasien. ${ }^{12}$

\section{Penyelesaian permasalahan akibat kelalaian dari pihak keluarga/wali pasien}

Upaya untuk permasalahan pihak keluarga yang tidak memenuhi kewajiban nya untuk menjemput pasien kembali yaitu pihak rumah sakit akan mengunjungi langsung alamat keluarga pasien untuk mengantarkan pasien tersebut untuk melakukan mediasi secara kekeluargaan dengan pihak keluarga pasien, dan cara terakhir jika tidak ada pihak keluarga yang bersedia menerima kembali pasien maka pihak rumah sakit akan menyerahkan pasien ke dinas sosial yang dapat menampung pasien karena tempat penampungan pasien pasca penyembuhan gangguan jiwa ini sangat penting, jika mereka telantar dan berkeliaran kembali maka penyakit mereka bisa saja akan kambuh kembali.

${ }^{9}$ Basuni, Tanggung Jawab Rumah Sakit Terhadap Pegawai Yang Melakukan Keslahan Tindakan Dalam Perawatan Pasien Gangguan Jiwa, Vol.14 No.2, 2014, hal. 111.

${ }^{10}$ Ibid, Hal. 112.

${ }^{11}$ Dian Apriyatni, S.Psi. Kepala Bagian Poli Psikologi Rumah Sakit Jiwa Jambi, Wawancara Penulis Pada Tanggal 4Juni 2020, Pada Pukul 10.30 WIB.

12 dr. Riza D. Staf Medis Rumah Sakit Jiwa Jambi, Wawancara penulis pada tanggal 8 Juni 2020, Pada Pukul 11.05 WIB. 


\section{SIMPULAN}

Berdasarkan hasil penelitian ini, maka dapat disimpulkan bahwa :

1. Pihak rumah sakit dan pasien terikat dalam suatu perjanjian baku yang didalamnya terdapat masing-masing hak dan kewajiban kedua belah pihak. Sebelum menandatangani perjanjian, pasien dijelaskan apa saja hak serta kewajiban yang harus dipatuhi, begitu juga hak serta kewajiban pihak rumah sakit itu sendiri. Perjanjian itu berisi penjelasan tentang hak dan kewajiban, persetujuan pelayanan kesehatan, akses informasi kesehatan, rahasia medis, pelepasan informasi, jaminan privasi/kerahasiaan penyakit pasien, dilarangnya membawa barang pribadi, pengajuan keluhan, kewajiban pembayaran, dan pelayanan kerohanian. Setelah sepakat maka ditanda tangani oleh kedua pihak.

2. Suatu perjanjian berisi hak serta kewajiban, maka ada beberapa permasalahan yang terjadi berkaitan dengan hak serta kewajiban yang telah disepakati tetapi tidak terpenuhi. Misalnya hak pasien/kewajiban rumah sakit yang tidak dipenuhi yaitu perlakuan negatif dari petugas kesehatan kepada pasien, kegiatan kerohanian yang tidak sesuai dengan prosedur yang dijadwalkan, atau sarana prasarana yang masih kurang memadai. Masalah-masalah tersebut bertentangan dengan hak pasien seperti: pasien berhak memperoleh layanan yang manusiawi, adil, jujur, dan tanpa diskriminasi; pasien berhak memperoleh layanan yang efektif dan efisien sehingga pasien terhindar dari kerugian fisik dan materi; pasien berhak memperoleh keamanan dan keselamatan dirinya selama dalam perawatan di rumah sakit; pasien berhak menggugat atau menuntut rumah sakit apabila rumah sakit diduga memberikan pelayanan yang tidak sesuai standar baik secara perdata maupun secara pidana. Sedangkan hak rumah sakit/kewajiban pasien/keluarga yang tidak dipenuhi yaitu pihak keluarga yang menelantarkan/tidak menjemput kembali pasien dirumah sakit jiwa, hal ini juga bertentangan dengan kewajiban pasien yaitu pasien dan keluarganya berkewajiban untuk menaati segala aturan dan tata tertib rumah sakit.

3. Upaya yang dilakukan untuk menyelesaikan pengaduan atau tuntutan dari penanggung jawab pasien (wali/keluarga) yaitu dengan cara mediasi antara rumah sakit dan pihak yang merasa dirugikan, karena dalam Undang-Undang Nomor 36 Tahun 2009 tentang Kesehatan dijelaskan bahwa jika ada tenaga kesehatan yang melakukan kelalaian maka harus diselesaikan terlebih dahulu dengan penyelesaian sengketa diluar pengadilan yaitu mediasi, karena proses penyelesaian mediasi bersifat fair, sehingga mendapatkan kesepakatan yang adil antara kedua belah pihak, sedangkan upaya untuk menyelesaikan masalah yang disebabkan karena kegiatan yang dilaksanakan kurang sempurna dan sarana prasarana yang kurang memadai yaitu dengan cara memaksimalkan kembali pelayanan yang tepat waktu dan mengusahakan kelengkapan sarana prasarana dari pihak rumah sakit sehingga tercapainya kepuasan pelayanan bagi pasien.

\section{DAFTAR PUSTAKA}

Ahmadi Miru, Hukum Kontrak dan Perancangan Kontrak, Jakarta:Rajawali Pers, 2007

Basuni, Tanggung Jawab Rumah Sakit Terhadap Pegawai Yang Melakukan Keslahan Tindakan Dalam Perawatan Pasien Gangguan Jiwa, Vol.14 No.2, 2014

Basuni, Tanggung Jawab Rumah Sakit Terhadap Pegawai Yang Melakukan Keslahan Tindakan Dalam Perawatan Pasien Gangguan Jiwa, Vol.14 No.2, 2014

Sarah Quroti A’yun, Dewi Hendrawati, Aminah, Pelaksanaan Perjanjian Terapeutik Antara Pasien Yang Mengalami Kegawatdaruratan Dengan Rs Bhayangkara Semarang, Diponegoro Law Journal, Volume 6 Nomor 2, 2017

Supeno, Dasar-Dasar Hukum Perikatan, Salim Media Indonesia, Jambi, 2019

Supeno, Hukum Kesehatan (Perlindungan Hak Pasien dan Penyelesaian Sengketa Medik), Salim Media Indonesia

Supeno, Kajian Yuridis Penyelesaian Sengketa Medik di Indonesia, Wajah Hukum, Volume 3 Nomor 2, 2019

J. Guwandi, Hukum Medik (Medical Law),Jakarta, Balai Penerbit FK UI, 2004 